Short Communication

\title{
Karyotype and genome size comparative analyses among six species of the oilseed-bearing genus Jatropha (Euphorbiaceae)
}

\author{
Anne C.T.A. Marinho ${ }^{1}$, Santelmo Vasconcelos ${ }^{2}$ (D), Emanuelle V. Vasconcelos ${ }^{1}$, Daniela A. Marques ${ }^{3}$, Ana \\ Maria Benko-Iseppon ${ }^{1}$ and Ana Christina Brasileiro-Vidal ${ }^{1}$ \\ ${ }^{1}$ Department of Genetics, Universidade Federal de Pernambuco, Recife, PE, Brazil. \\ ${ }^{2}$ Instituto Tecnológico Vale, Belém, PA, Brazil. \\ ${ }^{3}$ Centro de P\&D de Recursos Genéticos Vegetais, Instituto Agronômico, Campinas, SP, Brazil.
}

\begin{abstract}
Jatropha is an important genus of Euphorbiaceae, with species largely used for various purposes, including the manufacturing of soaps and pharmaceutical products and applications in the bioenergetic industry. Although there have been several studies focusing $\mathrm{J}$. curcas in various aspects, the karyotype features of Jatropha species are poorly known. Therefore, we analyzed six Jatropha species through fluorochrome staining (CMA/DAPI), fluorescent in situ hybridization (FISH) with 5 S and 45S rDNA probes and genome size estimation by flow cytometry. Our results revealed several chromosome markers by both CMA/DAPI and FISH for the analyzed species. Five Jatropha species (J. curcas, J. gossypiifolia, J. integerrima, J. multifida and J. podagrica) showed four CMA-positive $\left(\mathrm{CMA}^{+}\right)$bands associated with the $5 S$ and $45 S$ rDNA sites (one and two pairs, respectively). However, J. mollissima displayed six $\mathrm{CMA}^{+} / \mathrm{DAPI}$ bands co-localized with both $5 \mathrm{~S}$ and $45 \mathrm{~S}$ rDNA, which showed a FISH superposition. A gradual variation in the genome sizes was observed $(2 \mathrm{C}=0.64$ to $0.86 \mathrm{pg})$, although an association between evidenced heterochromatin and genome sizes was not found among species. Except for the unique banding pattern of $J$. mollissima and the pericentromeric heterochromatin of $J$. curcas and $J$. podagrica, our data evidenced relatively conserved karyotypes.
\end{abstract}

Keywords: Cytotaxonomy, DNA C-value, heterochromatin, physic nut, rDNA.

Received: May 04, 2017; Accepted: September 19, 2017.

Euphorbiaceae is one of the most complex and diverse angiosperm families, presenting a worldwide distribution, mainly in the Americas and in Africa. The group has approximately 8,000 species, including several genera with remarkable economic importance, such as Hevea (the rubber tree genus), Manihot (cassavas), Ricinus (castor) and Jatropha (Webster, 1987; Souza and Lorenzi, 2008). The genus Jatropha is composed of approximately 200 species (Webster, 1994; The Plant List, 2013), which present a vast biotechnological potential due to outstanding characteristics, such as drought tolerance, secondary metabolites with medicinal properties and high seed oil content and quality. The species $J$. gossypiifolia and $J$. podagrica, for instance, have an extensive use as ornamental plants, while $J$. ribifolia have been used as raw material for soaps and detergents. Both the oil and latex have been drawing attention by the pharmaceutical industry, due to their active principles that can be used in the production of

Send correpondence to Santelmo Vasconcelos, Instituto Tecnológico Vale - Desenvolvimento Sustentável, Rua Boaventura da Silva 955, 66055-090 Belém PA, Brazil. E-mail: santelmo.vasconcelos@itv.org. antiseptics, antifungals, healing drugs, laxatives, among other products (e.g., Anani et al., 2016; Shahinuzzaman et al., 2016; Sharma et al., 2016). On the other hand, fruits and seeds, mainly from $J$. curcas, present high oil content, also serving as a strategic crop to be used as an alternative raw material for the production of biofuels (Openshaw, 2000; Montes and Melchinger, 2016).

The domestication process and the enhancement of traits of interest of $J$. curcas is still in the beginning (Yue et al., 2013; Montes and Melchinger, 2016), although there has been a constant increase in the knowledge on the genetic variability of the species in the last decade (see, for instance, Guo et al., 2016), being improved considerably since the publication of the genome by Sato et al. (2011). Nevertheless, the vast majority of the species of Jatropha is poorly known, lacking even characterization studies aiming interspecific genetic similarities and karyotype information (Marques and Ferrari, 2008; Ovando-Medina et al., 2011, Marques et al., 2013).

In the general sense, Jatropha is supposed to present a high karyotypic stability, with the diploid number $2 n=22$ being reported for almost all the 31 analyzed species so far (see Rice et al., 2015), including J. curcas, J. gossypiifolia, 
J. integerrima, J. mollissima, J. multifida and J. podagrica, although J. cuneata Wiggins \& Rollins and J. dioica Sessé were reported as tetraploids $(2 n=44)$ (Miller and Webster, 1966; Dehgan and Webster, 1979; Sasikala and Paramathma, 2010). Also, both the chromosome morphologies and sizes have been reported as highly stable within the genus, with a predominance of small metacentric and submetacentric chromosomes (Deghan and Webster, 1979; Carvalho et al., 2008).

Basically, J. curcas is the only species with more refined analyses published, other than just chromosome counts, although there is an available genome size estimation for J. podagrica $(2 \mathrm{C}=0.60 \pm 0.05 \mathrm{pg}$; Vesely et al., 2012). Carvalho et al. (2008), for instance, presented a detailed karyotype analysis for $J$. curcas through standard staining and flow cytometry procedures, observing both small DNA content $(2 \mathrm{C}=0.85 \pm 0.01 \mathrm{pg})$ and small chromosomes (ranging between 1.24-1.71 $\mu \mathrm{m}$ ). Some authors have been assessing the physical distribution of large repetitive DNA clusters, such as rDNAs $5 \mathrm{~S}$ and $45 \mathrm{~S}$, as well as different copia-type retrotransposons and subtelomeric repetitions in the J. curcas karyotype, observing several chromosome markers for the species (Witkowska et al., 2009; Kikuchi et al., 2010; Alipour et al., 2013; Gong et al., 2013).

The economic importance of Jatropha species is noteworthy, and there is an evident need for more information regarding the genetic differentiation within the genus. Therefore, this work aimed to describe cytogenetic markers by means of CMA/DAPI banding and FISH with $5 \mathrm{~S}$ and 45S rDNA probes, besides providing genome size estimates, analyzing six species (Supplementary Table S1) largely used by several industry sectors, in order to contribute to a better understanding of the karyotype evolution of the genus.

Six Jatropha species were analyzed: $J$. curcas L., $J$. gossypiifolia L., J. integerrima Jacq., J. multifida L., J. mollissima (Pohl) Baill. and J. podagrica Hook (Figure 1). Root tips were collected either from germinated seeds or seedlings, pre-treated with $2 \mathrm{mM} 8$-hydroxyquinolein (8$\mathrm{HQ})$ for $4.5 \mathrm{~h}$ at $18{ }^{\circ} \mathrm{C}$. The material was fixed in methanol:acetic acid $(3: 1, \mathrm{v} / \mathrm{v})$ for at least $4 \mathrm{~h}$ and then stored at $-20{ }^{\circ} \mathrm{C}$. The preparation of slides followed the protocol described by Carvalho and Saraiva (1993), with modifications introduced by Vasconcelos et al. (2010).

After preparation, the slides were stored for three days at room temperature $\left(\sim 25^{\circ} \mathrm{C}\right)$ and then stained with $0.5 \mathrm{mg} / \mathrm{mL} \mathrm{CMA} \mathrm{for} 1 \mathrm{~h}$ and $2 \mu \mathrm{g} / \mathrm{mL}$ DAPI for $30 \mathrm{~min}$, mounted in McIlvaine's buffer (pH 7.0): glycerol (1:1, v/v) and stored for another three days (Schweizer and Ambros, 1994). After image capture, slides were destained in ethanol:acetic acid $(3: 1, \mathrm{v} / \mathrm{v})$ for $30 \mathrm{~min}$ at room temperature, followed by immersion in ethanol for $1 \mathrm{~h}$ and storage at -20 ${ }^{\circ} \mathrm{C}$.
The following probes were used in the FISH procedures: (1) R2, a $6.5 \mathrm{~kb}$ fragment containing the 18S-5.8S25S rDNA repeat unit from Arabidopsis thaliana (L.) Heynh. (Wanzenböck et al., 1997), and (2) D2, a 400 bp containing two 5S rDNA repeat units from Lotus corniculatus L. [as L. japonicus (Regel) K.Larsen] (Pedrosa et al., 2002), which were labeled by nick translation with digoxigenin-11-dUTP (Roche Diagnostics) and biotin-11dUTP (Sigma), respectively. The FISH pre-treatment and post-hybridization washes followed Pedrosa et al. (2002), in which the stringency wash $(77 \%)$ was performed with $0.1 \mathrm{X} \mathrm{SSC}$ at $42{ }^{\circ} \mathrm{C}$. Chromosome and probe denaturation and detection were performed according to Heslop-Harrison et al. (1991). Ten microliters of the hybridization mixture, which contained $50 \%$ formamide (v/v), 2X SSC, $10 \%$ dextran sulfate $(\mathrm{w} / \mathrm{v})$ and $2.5-5 \mathrm{ng} / \mu \mathrm{L}$ of the probe, were added to each slide, being hybridized at $37^{\circ} \mathrm{C}$ for at least $18 \mathrm{~h}$. Detection of the digoxigenin-labelled probes was carried out using sheep anti-digoxigenin-FITC (Roche Diagnostics), and the signal was amplified with donkey anti-sheep-FITC (Sigma), in 1\% (w/v) BSA. Biotin-labelled probes were detected with mouse anti-biotin (Dako), and the signal was visualized with rabbit anti-mouse TRITC conjugate (Dako), in 1\% (w/v) BSA. Preparations were counterstained and mounted with $2 \mu \mathrm{g} / \mathrm{mL}$ DAPI in Vectashield (Vector) $(1: 1 ; \mathrm{v} / \mathrm{v})$.

Images of the cells were captured on a Leica DMLB microscope with a Leica DFC 340FX camera, using the software Leica CW4000, with optimization for contrast and brightness using Adobe Photoshop CC (Adobe Systems Incorporated) software.

The DNA 2C-values were measured by using approximately 20-30 mg of fresh leaves of the six species, each with an internal reference standard (Solanum lycopersicum $\mathrm{cv}$. Stupicke polni tyckove, $2 \mathrm{C}=1.96 \mathrm{pg}$ ), being chopped in $1 \mathrm{~mL}$ of WPB buffer (Loureiro et al., 2007), following the procedures described by Dolezel et al. (1989). The nuclei suspension was filtered through a $30 \mu \mathrm{m}$ nylon mesh and then stained with $30 \mu \mathrm{L}$ of $1 \%$ propidium iodide $(w / v)$. Three individuals per species were analyzed and three replicates per individual, with at least 10,000 nuclei per sample, using the Partec CyFlow Space flow cytometer. Each histogram obtained from the relative fluorescence of the nuclei of the samples and the internal reference was analyzed in the software Partec FloMax 2.4. Afterward, the mean DNA 2C-values were calculated after discarding both the smallest and the largest readings obtained for each species.

All analyzed karyotypes presented the diploid number $2 n=22$, with chromosomes predominantly metacentric and submetacentric (Table 1; Figures 2 and 3), as well as semi-reticulated interphase nucleus, confirming previous counts for all six species (Perry, 1943; Miller and Webster, 1962; Miller and Webster, 1966). Additionally, at least two satellited chromosomes were visualized for all six species. 

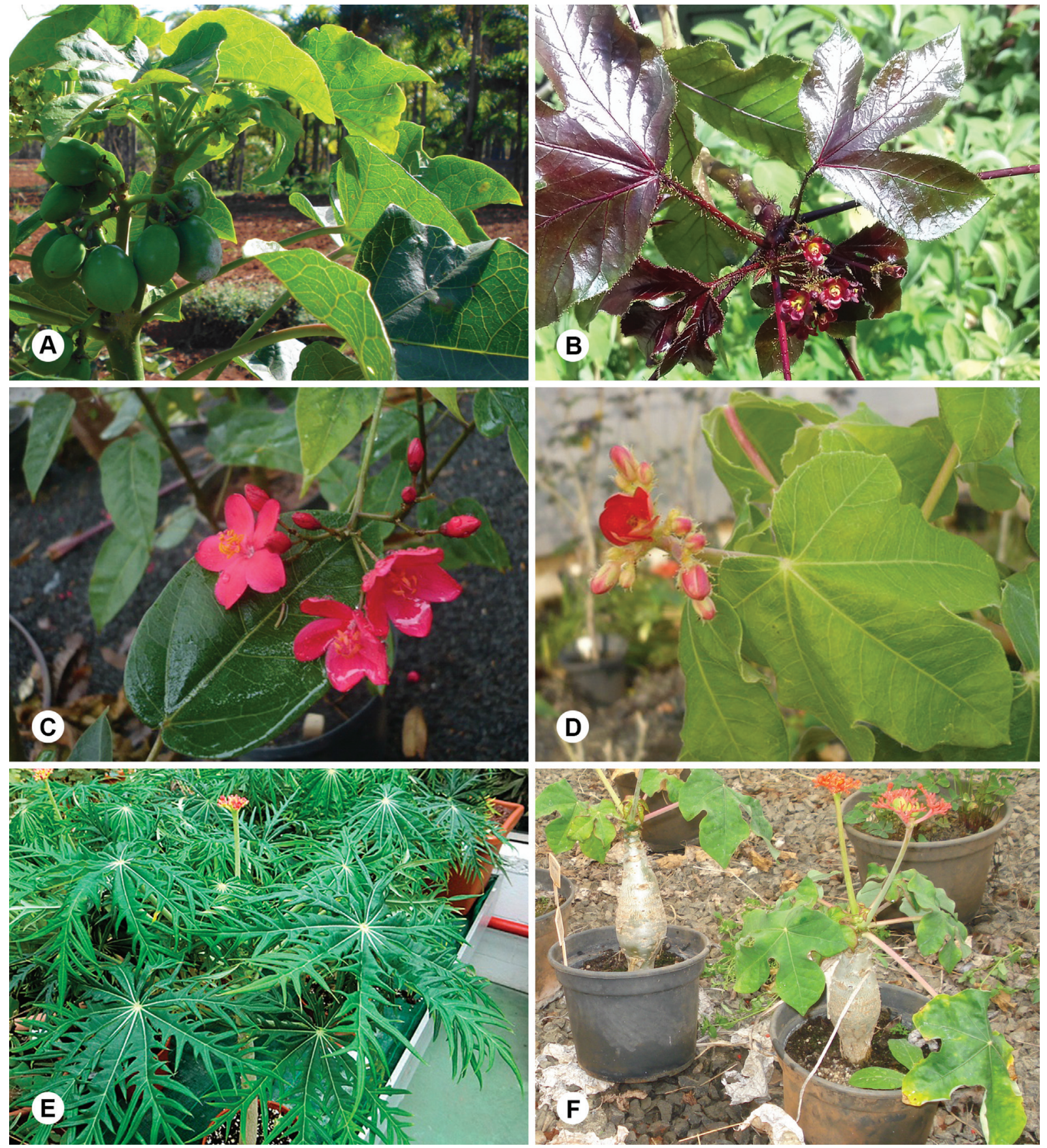

Figure 1 - Representatives of the six analyzed Jatropha species: (A) Jatropha curcas; (B) J. gossypiifolia; (C) J. integerrima; (D) J. mollissima; (E) J. multifida; and (F) J. podagrica.

The CMA/DAPI staining revealed four chromosomes with terminal $\mathrm{CMA}^{+} / \mathrm{DAPI}^{-}$bands for $J$. curcas, $J$. gossypiifolia, J. integerrima, J. multifida and J. podagrica (Figures 2A-C,E,F and 4A-C,E,F). However, J. mollissima diverged from the other five species by showing six terminal $\mathrm{CMA}^{+} / \mathrm{DAPI}^{-}$bands (Figures 2D and 4D). In addition, $J$. curcas and $J$. podagrica presented pericentromeric $\mathrm{CMA}^{+} / \mathrm{DAPI}^{-}$bands in all chromosomes, although they were not always clear, depending on the condensation level of the chromosomes (Table 1; Figures 2A,B,F and
4A,B-F). Also, depending on the chromatin condensation level, terminal $\mathrm{CMA}^{+} / \mathrm{DAPI}^{-}$dots were visible in almost all chromosome arms of $J$. curcas (Figures 2A and 4A). The high amount of $\mathrm{CMA}^{+}$heterochromatin (GC-rich) is in accordance to Guo et al. (2016), who reported an average $\mathrm{G}+\mathrm{C}$ content of $65.04 \%$ for $J$. curcas. The pericentromeric heterochromatin in J. curcas is at least partially related to gypsy-type retrotransposons (Alipour et al., 2014), while terminal heterochromatic dots are related to copia-type retrotransposons (Alipour et al., 2013). These patterns of 
Table 1 - Karyotype characterization of the six analyzed Jatropha species, showing diploid chromosome numbers (2n); distribution pattern of CMA+/DAPI bands and 5S and 45S rDNA sites; genome size estimation (pg) and mean CV (\%) per species.

\begin{tabular}{|c|c|c|c|c|c|c|c|}
\hline Species & Accessions and provenances & $2 n$ & $\mathrm{CMA}^{+} / \mathrm{DAPI}^{-}$ & 45S rDNA & 5S rDNA & $2 \mathrm{C}(\mathrm{pg})$ & $\mathrm{CV}(\%)$ \\
\hline J. curcas $\mathrm{L}^{1}{ }^{1}$ & $\begin{array}{l}\text { LGBV-S2860; Embrapa Algo- } \\
\text { dão, Patos, PB, Brazil }\end{array}$ & 22 & $4 \mathrm{~T}^{2}, \mathrm{P}^{3}$ & $4 \mathrm{~T}$ & $2 \mathrm{ST}^{4}$ & $0.86 \pm 0.02$ & 3.95 \\
\hline J. gossypiifolia $\mathrm{L}$. & $\begin{array}{l}\text { LGBV-S3313; Engenho Ubu, BR } \\
101 \text { Norte, Km 24, Goiana, PE, } \\
\text { Brazil }\end{array}$ & 22 & $4 \mathrm{~T}, \mathrm{P}$ & $4 \mathrm{~T}$ & $2 \mathrm{ST}$ & $0.64 \pm 0.02$ & 4.14 \\
\hline J. integerrima Jacq. & $\begin{array}{l}\text { IAC-VI23; Instituto Agronômico } \\
\text { (IAC), Campinas, SP, Brazil }\end{array}$ & 22 & $4 \mathrm{~T}$ & $4 \mathrm{~T}$ & $2 \mathrm{ST}$ & $0.85 \pm 0.03$ & 4.27 \\
\hline J. mollissima (Pohl) Baill. ${ }^{1}$ & $\begin{array}{l}\text { LGBV-S3314; Parque Nacional do } \\
\text { Catimbau, Buíque, PE, Brazil }\end{array}$ & 22 & $5 \mathrm{~T}+1 \mathrm{ST}$ & $5 \mathrm{~T}+1 \mathrm{ST}$ & $5 \mathrm{~T}+1 \mathrm{ST}$ & $0.79 \pm 0.03$ & 5.53 \\
\hline J. multifida L. $^{1}$ & $\begin{array}{l}\text { IAC-V1P1; Instituto Agronômico } \\
\text { (IAC), Campinas, SP, Brazil }\end{array}$ & 22 & $4 \mathrm{~T}$ & $4 \mathrm{~T}$ & $2 \mathrm{ST}$ & $0.64 \pm 0.01$ & 5.17 \\
\hline J. podagrica Hook. ${ }^{1}$ & LGBV-S2844; Gravatá, PE, Brazil & 22 & $4 \mathrm{~T}, \mathrm{P}$ & $4 \mathrm{~T}$ & $2 \mathrm{ST}$ & $0.74 \pm 0.05$ & 6.65 \\
\hline
\end{tabular}

${ }^{1}$ Cultivated in the green house of the Department of Genetics, Universidade Federal de Pernambuco, Recife, Brazil; ${ }^{2} \mathrm{~T}-$ terminal signals; ${ }^{3} \mathrm{P}-$ pericentromeric signals in all chromosomes; ${ }^{4} \mathrm{ST}$ - subterminal signals.
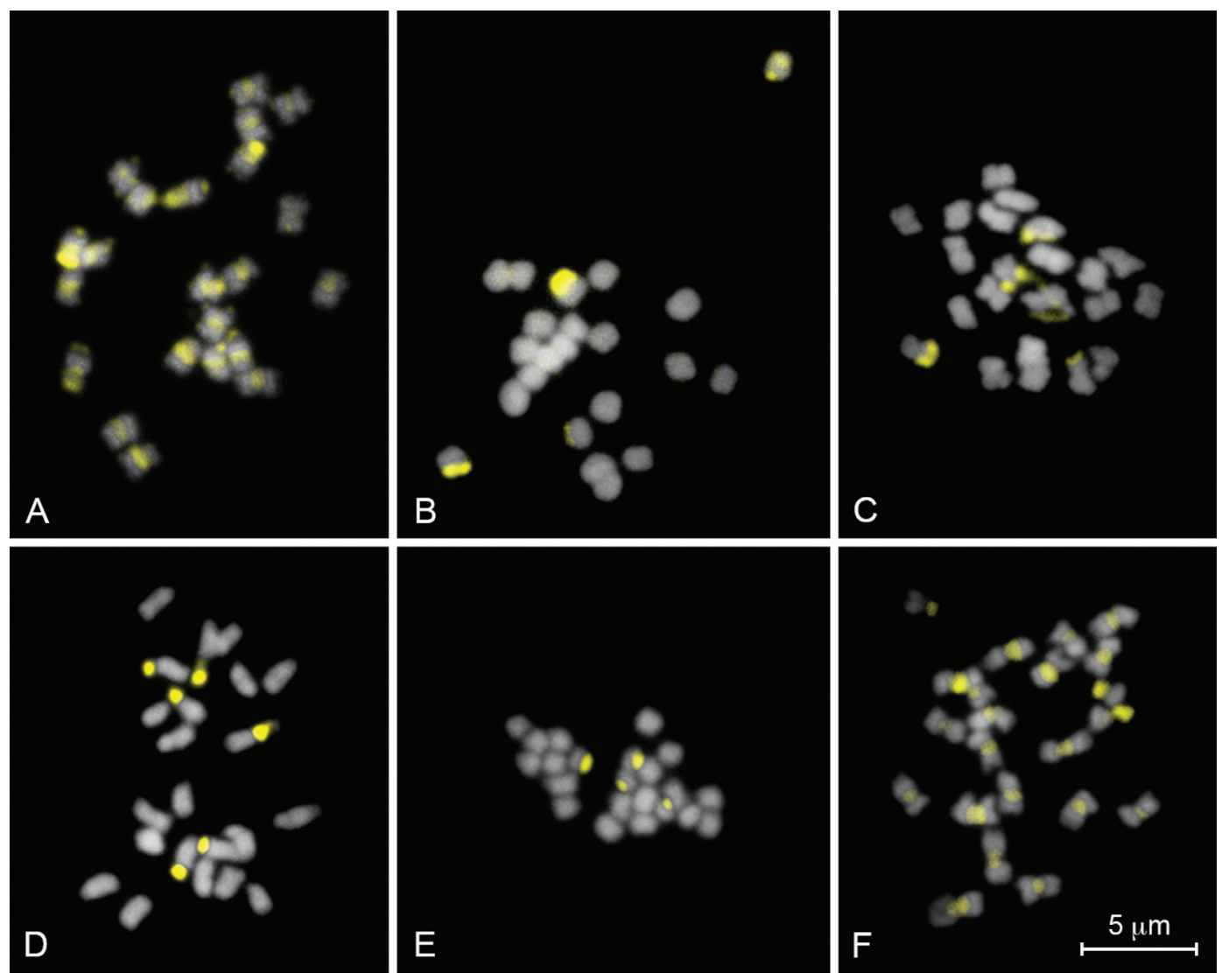

Figure 2 - Mitotic metaphases of six Jatropha species stained with chromomycin A $(\mathrm{CMA})$ and 4',6-diamidino-2-phenylindole (DAPI), evidencing CMA+/DAPI" bands in yellow: (A) Jatropha curcas; (B) J. gossypiifolia; (C) J. integerrima; (D) J. mollissima; (E) J. multifida; and (F) J. podagrica.

heterochromatin rich karyotypes have also been described for other Euphorbiaceae species, such as castor (Ricinus communis L.), Euphorbia characias L., E. hirta L., E. hyssopifolia L., Manihot dichotoma Ule and M. esculenta Crantz (Carvalho and Guerra, 2002; D'Emerico et al., 2003; Vasconcelos et al., 2010; Santana et al., 2016).
Five out of the six analyzed species ( $J$. curcas, $J$. gossypiifolia, $J$. integerrima, $J$. multifida, and $J$. podagrica) presented one $5 \mathrm{~S}$ and two $45 \mathrm{~S}$ rDNA site pairs, both co-localized with $\mathrm{CMA}^{+} / \mathrm{DAPI}^{-}$bands, with an apparent adjacency between the $5 \mathrm{~S}$ rDNA and one of the $45 \mathrm{~S}$ rDNA pairs (Figures 3A-C,E,F and 4A-C,E,F). On the 


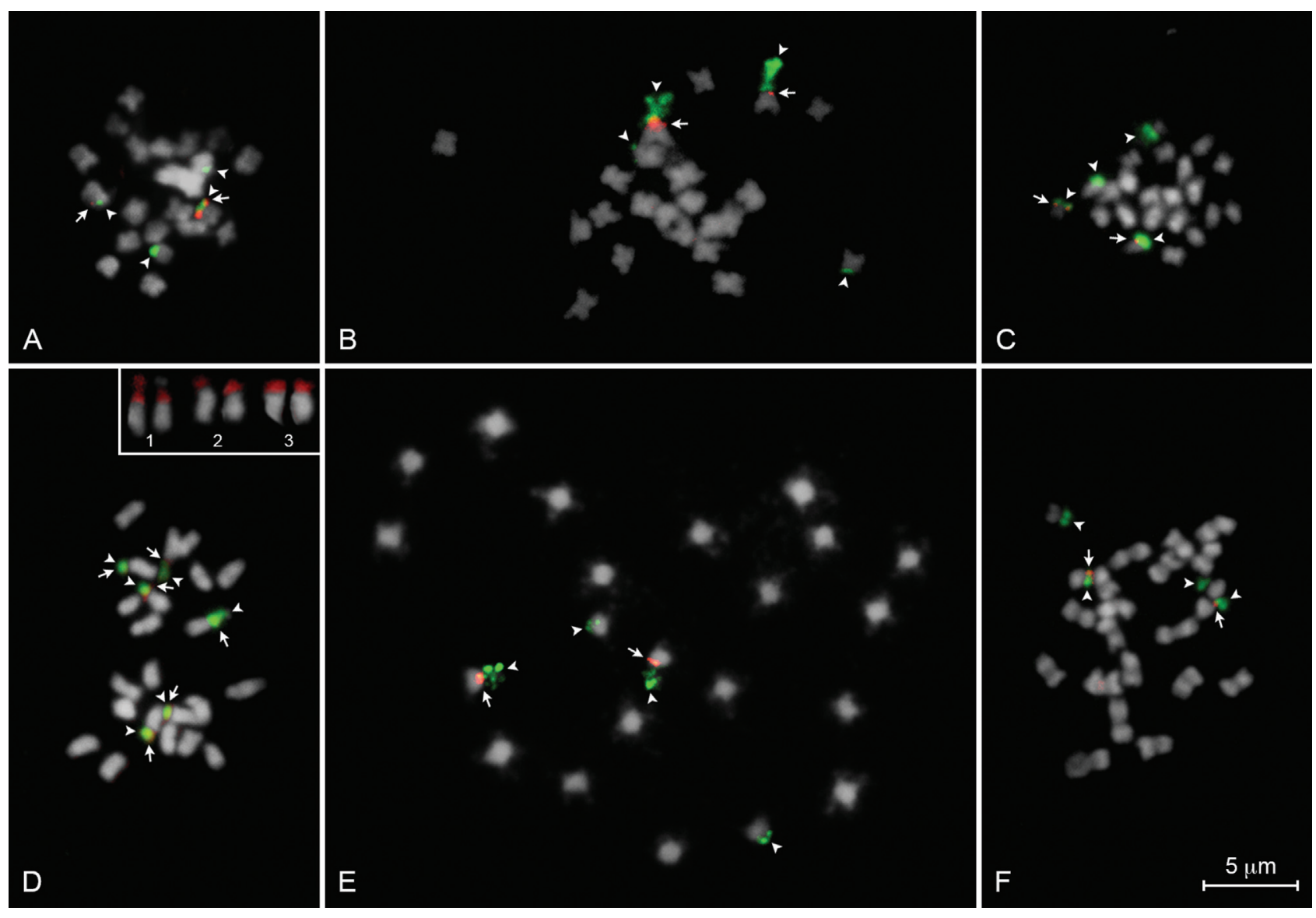

Figure 3 - Localization of 5S (red) and 45S (green) rDNA sites in mitotic metaphases of six Jatropha species: (A) Jatropha curcas; (B) J. gossypiifolia; (C) J. integerrima; (D) J. mollissima; (E) J. multifida; and (F) J. podagrica. Arrows and arrowheads indicate the $5 \mathrm{~S}$ and $45 \mathrm{~S}$ rDNA sites, respectively. Numbers in D evidence the 5S rDNA sites in J. mollissima.

other hand, J. mollissima presented six chromosomes with a co-localization between $5 \mathrm{~S}$ and $45 \mathrm{~S}$ rDNA sites, which also corresponded to $\mathrm{CMA}^{+} / \mathrm{DAPI}^{-}$bands (Figures $3 \mathrm{D}$ and 4D). Furthermore, one of these three chromosome pairs of J. mollissima presented a heteromorphism: one of the chromosomes of the pair 1 presented a smaller 5S rDNA, not covering the satellited region (Figure 3D). Data for number and distribution of $5 \mathrm{~S}$ and $45 \mathrm{~S}$ rDNA sites in $J$. curcas corroborated previous data for the species (Witkowska et al., 2009). For the remaining species, rDNA data are being reported for the first time in the present work.

Both the number and the distribution patterns of $5 \mathrm{~S}$ and $45 \mathrm{~S}$ rDNA sites seem to be quite conserved in Jatropha, although the superposition of $5 \mathrm{~S}$ and $45 \mathrm{~S}$ rDNA sites and the presence of 5S rDNA in more than one chromosome pair in J. mollissima are reported for the first time in a species of Euphorbiaceae (see, for instance, Carvalho and Guerra, 2002; Vasconcelos et al., 2010; Santana et al., 2016). Furthermore, the presence of both $5 \mathrm{~S}$ and $45 \mathrm{~S}$ rDNA sites in the same chromosome arm is not common in the family, and it has been observed only in E. hyssopifolia so far (Santana et al., 2016). Nevertheless, besides the peculiar distribution pattern of the rRNA genes in J. mollissima, the heteromorphism observed in one chromosome pair of the species may indicate a derived karyotype within the genus. This condition may be related to active transposable elements associated with rDNA amplification, considering the abundance of such repetitive DNA in heterochromatic regions (Eickbush and Eickbush, 2007; Schubert, 2007; Roa and Guerra, 2015). For instance, the terminal regions of $J$. curcas chromosomes are rich in copia-type elements, including the 5S rDNA bearer (Alipour et al., 2013). On the other hand, one cannot discard the possibility of additional cryptic rDNA sites that could not be evidenced by FISH in the other five analyzed karyotypes (see Cabrero and Camacho, 2008; Vasconcelos et al., 2010; Roa and Guerra, 2015). The co-localization of $5 \mathrm{~S}$ and $45 \mathrm{~S}$ rDNA FISH sites is very uncommon in angiosperms, being reported only for a few Asteraceae species, as a consequence of an interspersed position of both unit genes (Garcia et al., 2010). Such a feature hardly guarantees any evolutionary advantage due to the differences in gene functionalities between the two types of rDNAs. These are probably associated with proliferation mechanisms of transposable elements (Ciganda and Williams, 2011; Roa and Guerra, 2015), and more frequently observed in gymnosperms (Garcia and 
A

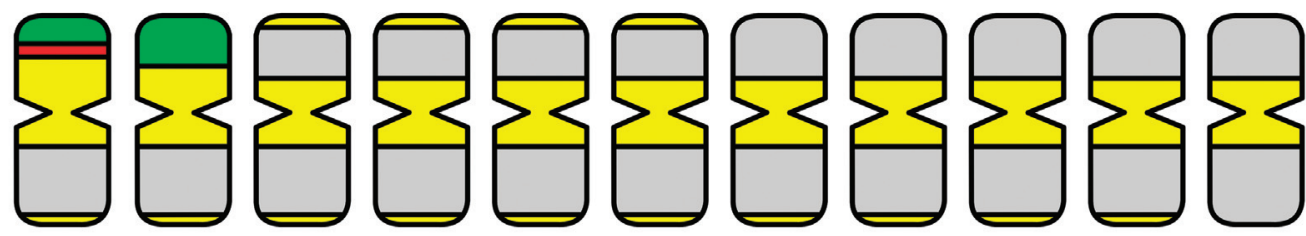

B

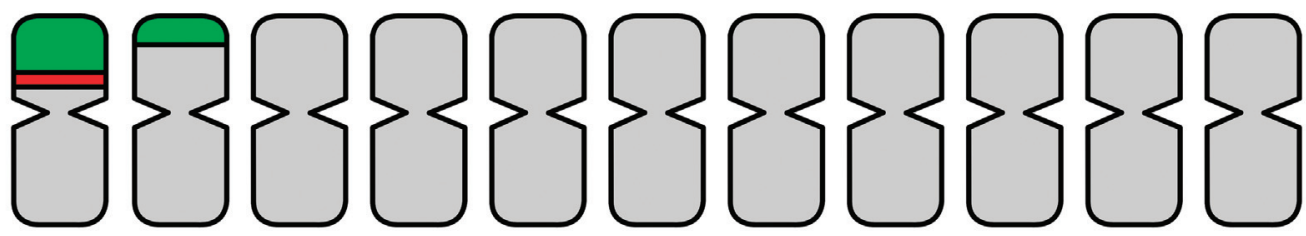

C

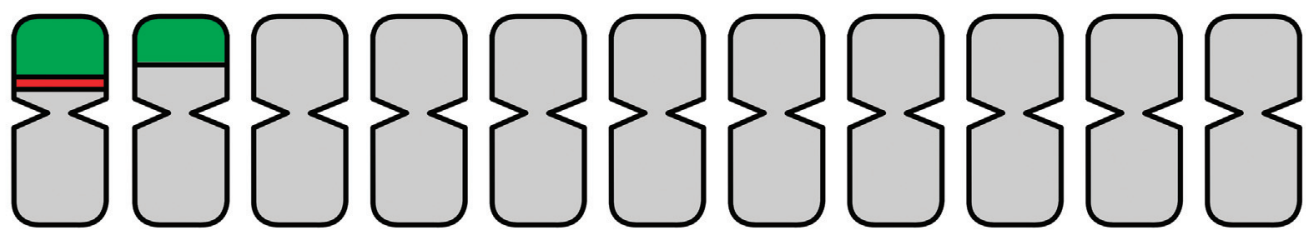

D

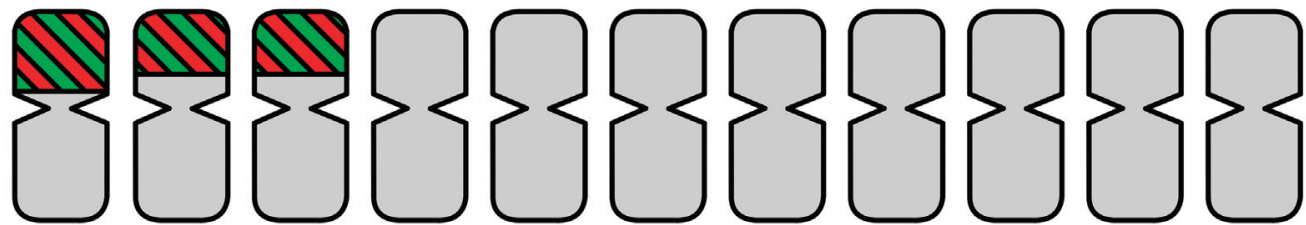

E
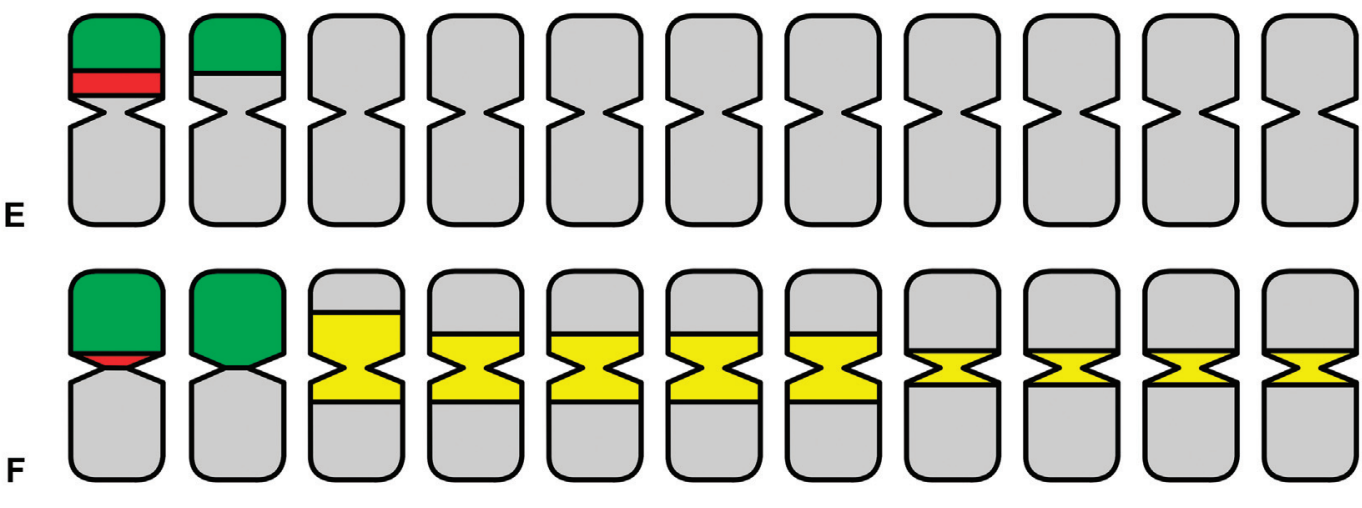

rDNA 45S/CMA ${ }^{+}$

rDNA 5S/CMA ${ }^{+}$

$\mathrm{CMA}^{+}$

Figure 4 - Representative idiograms of cytogenetic markers in all chromosome pairs of six Jatropha species. (A) Jatropha curcas; (B) J. gossypiifolia; (C) J. integerrima; (D) J. mollissima; (E) J. multifida; and (F) J. podagrica. It is important to note that only chromosome markers are evidenced in the idiograms, and actual chromosome sizes and arm ratios were not represented. Also, due to the high variation in the presence of the terminal $\mathrm{CMA}^{+}$bands in the $J$. curcas karyotype, depending on the condensation level of the chromosomes, only signals always visualized were represented.

Kovarik, 2013) and in early diverging land plants (Wicke et al., 2011).

The flow cytometry analysis revealed a variation of DNA content among the analyzed species ranging between $2 \mathrm{C}=0.64 \mathrm{pg}$ for $J$. gossypiifolia and $J$. multifida and $2 \mathrm{C}=$ $0.86 \mathrm{pg}$ for $J$. curcas (Table 1). For $J$. gossypiifolia $(2 \mathrm{C}=$ $0.64 \pm 0.02 \mathrm{pg})$, J. integerrima $(0.85 \pm 0.03)$, J. mollissima $(0.79 \pm 0.03)$ and $J$. multifida $(2 \mathrm{C}=0.64 \pm 0.01 \mathrm{pg})$ the genome sizes were estimated for the first time (Table 1). For $J$. curcas, the $2 \mathrm{C}$-value obtained here $(2 \mathrm{C}=0.86 \pm 0.02 \mathrm{pg})$ was similar to the previously reported by Carvalho et al.
(2008) $(2 \mathrm{C}=0.85 \pm 0.01 \mathrm{pg})$. On the other hand, our results for $J$. podagrica $(2 \mathrm{C}=0.74 \pm 0.05 \mathrm{pg})$ were different from the obtained by Vesely et al. (2012) $(2 \mathrm{C}=0.60 \pm 0.05 \mathrm{pg})$. This discrepancy may be occurred either due to differences between the internal reference standards used in the two analyses (Tiryaki and Tuna, 2012) or due to an intraspecific polymorphism in $J$. podagrica related to variations in the repetitive DNA content. Although the six species present the same chromosome number, the observed variation in the genome sizes $(1.34 \mathrm{x})$ reinforces the importance of DNA content estimations in order to understand the karyotype 
evolution of homoploid species (Loureiro et al., 2010), helping the planning of interspecific crosses for breeding purposes.

The cytogenetic features reported here revealed different patterns of heterochromatin distribution for the first time for five Jatropha species and confirmed the previous data for $J$. curcas, besides allowing the identification of chromosome markers for the genus: (1) J. curcas and $J$. podagrica with an accumulation of pericentromeric heterochromatin; (2) five species, including J. curcas, with a conserved number and distribution of $5 \mathrm{~S}$ and $45 \mathrm{~S}$ rDNA; (3) $5 \mathrm{~S}$ rDNA sites detected as $\mathrm{CMA}^{+}$; (4) J. mollissima as the first reported species with more than one pair of $5 \mathrm{~S}$ rDNA sites in Euphorbiaceae and with a distinct distribution (with FISH superposition) of $5 \mathrm{~S}$ and $45 \mathrm{~S}$ rDNA; (5) no apparent correlation between genome size and revealed heterochromatin.

\section{Acknowledgments}

The authors would like to thank the Brazilian National Council for Scientific and Technological Development (Conselho Nacional de Desenvolvimento Científico e Tecnológico - CNPq) for financial support.

\section{References}

Alipour A, Tsuchimoto S, Sakai H, Ohmido N and Fukui K (2013) Structural characterization of copia-type retrotransposons leads to insights into the marker development in a biofuel crop, Jatropha curcas L. Biotechnol Biofuels 6:129.

Alipour A, Cartagena JA, Tsuchimoto S, Sakai H, Ohmido N and Fukui K (2014) Identification and characterization of novel gypsy-type retrotransposons in a biodiesel crop, Jatropha curcas L. Plant Mol Biol Rep 32:923-930.

Anani K, Adjrah Y, Améyapoh Y, Karou SD, Agbonon A, de Souza C and Gbeassor M (2016) Antimicrobial, anti-inflammatory and antioxidant activities of Jatropha multifida L. (Euphorbiaceae). Pharmacognosy Res 8:142-146.

Cabrero J and Camacho JPM (2008) Location and expression of ribosomal RNA genes in grasshoppers: abundance of silent and cryptic loci. Chromosome Res 16:595-607.

Carvalho CR and Saraiva LS (1993) An air drying technique for maize chromosomes without enzymatic maceration. Biotech Histochem 68:142-145.

Carvalho CR, Clarindo WR, Praça MM, Araújo FS and Carels N (2008) Genome size, base composition and karyotype of Jatropha curcas L., an important biofuel plant. Plant Sci 174:613-617.

Carvalho R and Guerra M (2002) Cytogenetics of Manihot esculenta Crantz (cassava) and eight related species. Hereditas 136:159-168.

Ciganda M and Williams N (2011) Eukaryotic 5S rRNA biogenesis. Wiley Interdiscip Rev RNA 2:523-533.

Dehgan B and Webster GL (1979) Morphology and infrageneric relationships of the genus Jatropha (Euphorbiaceae). U Calif Publ Bot 74:1-73.

D'Emerico S, Pignone D, Vita F and Scrugli A (2003) Karyomorphological analyses and chromatin characterization by banding techniques in Euphorbia characias L. and E. wulfenii Hoppe (= E. veneta Willd.) (Euphorbiaceae). Caryologia 56:501-508.

Dolezel J, Binarova P and Lucretti S (1989) Analysis of nuclear DNA content in plant cells by flow cytometry. Biol Plantarum 31:113-120.

Eickbush TH and Eickbush DG (2007) Finely orchestrated movements: evolution of the ribosomal RNA genes. Genetics 175:477-485.

Garcia S, Panero JL, Siroky J and Kovarik A (2010) Repeated reunions and splits feature the highly dynamic evolution of $5 \mathrm{~S}$ and $35 \mathrm{~S}$ ribosomal RNA genes (rDNA) in the Asteraceae family. BMC Plant Biol 10:176.

Garcia S and Kovarik A (2013) Dancing together and separate again: gymnosperms exhibit frequent changes of fundamental 5S and 35S rRNA gene (rDNA) organisation. Heredity 111:23-33.

Gong Z, Xue C, Zhang M, Guo R, Zhou Y, and Shi G (2013). Physical localization and DNA methylation of 45S rRNA gene loci in Jatropha curcas L. PLoS One 8:e84284.

Guo GY, Chen F, Shi XD, Tian YS, Yu MQ, Han XQ, Yuan LC and Zhang Y (2016) Genetic variation and phylogenetic relationship analysis of Jatropha curcas L. inferred from nrDNA ITS sequences. C R Biol 339:337-346.

Heslop-Harrison JS, Schwazarcher T, Anamthawat-Jónsson K, Leitch AR and Shi M (1991) In situ hybridization with automated chromosome denaturation. Technique 3:109-115.

Kikuchi S, Tsujimoto H, Sassa H and Koba T (2010). JcSat1, a novel subtelomeric repeat of Jatropha curcas L. and its use in karyotyping. Chromosome Sci 13:11-16.

Loureiro J, Rodriguez E, Dolezel J and Santos C (2007) Two new nuclear isolation buffers for plant DNA flow cytometry: a test with 37 species. Ann Bot 100:875-888.

Loureiro J, Travnicek P, Rauchova J, Urfus T, Vit P, Stech M, Castro S and Suda J (2010) The use of flow cytometry in the biosystematics, ecology and population biology of homoploid plants. Preslia 82:3-21.

Marques DA and Ferrari RA (2008) O papel das novas biotecnologias no melhoramento genético do pinhão-manso. Biológico 70:65-67.

Marques DA, Siqueira WJ, Colombo CA and Ferrari RA (2013) Breeding and biotechnology of Jatropha curcas. In: Bahadur B, Sujatha M and Carels N (eds) Jatropha, challenges for a new energy crop (V2): Genetic improvement and biotechnology. Springer, New York, pp 457-478.

Miller KI and Webster GL (1962) Systematic position of Cnidoscolus and Jatropha. Brittonia 14:174-180.

Miller KI and Webster GL (1966) Chromosome numbers in the Euphorbiaceae. Brittonia 18:372-379.

Montes JM and Melchinger AE (2016) Domestication and breeding of Jatropha curcas L. Trends Plant Sci 21:1045-1057.

Openshaw K (2000) A review of Jatropha curcas: an oil plant of unfulfilled promise. Biomass Bioenerg 19:1-15.

Ovando-Medina I, Espinosa-García FJ, Núñez-Farfán JS and Salvador-Figueroa M (2011) State of the art of genetic diversity research in Jatropha curcas. Sci Res Essays 6:1709-1719.

Pedrosa A, Sandal N, Stougaard J, Schweizer D and Bachmair A (2002) Chromosomal map of the model legume Lotus japonicus. Genetics 161:1661-1672.

Perry BA (1943) Chromosome number and phylogenetic relationships in the Euphorbiaceae. Am J Bot 30:527-543. 
Rice A, Glick L, Abadi S, Einhorn M, Kopelman NM, SalmanMinkov A, Mayzel J, Chay O and Mayrose I (2015) The chromosome counts database (CCDB) - a community resource of plant chromosome numbers. New Phytol 206:1926.

Roa F and Guerra M (2015) Non-random distribution of 5S rDNA sites and its association with 45S rDNA in plant chromosomes. Cytogenet Genome Res 146:243-249.

Santana KCB, Pinangé DSB, Vasconcelos S, Oliveira AR, Brasileiro-Vidal AC, Alves MV and Benko-Iseppon AB (2016) Unraveling the karyotype structure of the spurges Euphorbia hirta L. and E. hyssopifolia L. (Euphorbiaceae) using genome size estimation and heterochromatin differentiation. Comp Cytogenet 10:657-696.

Sasikala R and Paramathma M (2010) Chromosome studies in the genus Jatropha L. Electron J Plant Breeding 4:637-642.

Sato S, Hirakawa H, Isobe S, Fukai E, Watanabe A, Kato M, Kawashima K, Minami C, Muraki A, Nakazaki N, et al. (2011) Sequence analysis of the genome of an oil-bearing tree, Jatropha curcas L. DNA Res 18:65-76.

Schubert I (2007) Chromosome evolution. Curr Opin Plant Biol 10:109-115.

Schweizer D and Ambros PF (1994) Chromosome banding. In: Gosden JR (ed) Methods in Molecular Biology. Humana Press, Totowa, pp 97-112.

Shahinuzzaman M, Yaakob Z and Moniruzzaman M (2016) Medicinal and cosmetics soap production from Jatropha oil. J Cosmet Dermatol 15:185-193.

Sharma AK, Gangwar M, Kumar D, Nath G, Kumar Sinha AS and Tripathi YB (2016) Phytochemical characterization, antimicrobial activity and reducing potential of seed oil, latex, machine oil and presscake of Jatropha curcas. Avicenna J Phytomed 6:366-375.

Souza VC and Lorenzi H (2008) Botânica Sistemática: Guia ilustrado para identificação das famílias de fanerógamas nativas e exóticas no Brasil, baseado em APG II. 2nd edition. Instituto Plantarum, São Paulo, 704 p.

Tiryaki I and Tuna M (2012) Determination of intraspecific nuclear DNA content variation in common vetch (Vicia sativa L.) lines and cultivars based on two distinct internal reference standards. Turk J Agric For 36:645-653.

Vasconcelos S, Souza AA, Gusmão CLS, Milani M, BenkoIseppon AM and Brasileiro-Vidal AC (2010) Heterochro- matin and rDNA $5 \mathrm{~S}$ and $45 \mathrm{~S}$ sites as reliable cytogenetic markers for castor bean (Ricinus communis, Euphorbiaceae). Micron 41:746-753.

Vesely P, Bures P, Smarda P and Pavlicek T (2012) Genome size and DNA base composition of geophytes: The mirror of phenology and ecology? Ann Bot 109:65-75.

Wanzenböck EM, Schöfer C, Schweizer D and Bachmair A (1997) Ribosomal transcription units integrated via T-DNA transformation associate with the nucleolus and do not require upstream repeat sequences for activity in Arabidopsis thaliana. Plant J 11:1007-1016.

Webster GL (1987) The saga of the spurges: A review of classification and relationships in the Euphorbiales. Bot J Linn Soc 94:3-46.

Webster GL (1994) Synopsis of the genera and suprageneric taxa of Euphorbiaceae. Ann Mo Bot Gard 81:33-144.

Wicke S, Costa A, Muñoz J and Quandt D (2011) Restless 5S: The re-arrangement(s) and evolution of the nuclear ribosomal DNA in land plants. Mol Phylogenet Evol 61:321-332.

Witkowska M, Ohmido N, Cartagena J, Shibagaki N, Kajiyama S and Fukui K (2009) Physical mapping of ribosomal DNA genes on Jatropha curcas chromosomes by multicolor FISH. Cytologia 74:133-139.

Yue GH, Sun F and Liu P (2013) Status of molecular breeding for improving Jatropha curcas and biodiesel. Renew Sust Energ Rev 26:332-343.

\section{Internet Resources}

The Plant List (2013). Version 1.1, http://www.theplantlist.org/ (October 19, 2016).

\section{Supplementary material}

The following online material is available for this article: Table S1 - Traits of agronomic interest of the six analyzed species of Jatropha.

Associate Editor: Everaldo Gonçalves de Barros

License information: This is an open-access article distributed under the terms of the Creative Commons Attribution License (type CC-BY), which permits unrestricted use, distribution and reproduction in any medium, provided the original article is properly cited. 